\title{
Pengaruh Susu Kedelai dan Bubur Kacang Hijau terhadap Lingkar Pinggang Wanita Pascamenopause
}

\author{
The Effect of Soy Milk and Mung Bean Porridge on Waist Circumference \\ among Postmenopausal Women
}

\author{
Fendie K. Syailawan ${ }^{1 *}$, Budiyanti Wiboworini ${ }^{1}$, Lilik Retna Kartikasari ${ }^{2}$ \\ ${ }^{1}$ Program Studi Magister Ilmu Gizi, Pascasarjana, Universitas Sebelas Maret, Surakarta \\ ${ }^{2}$ Fakultas Pertanian, Universitas Sebelas Maret, Surakarta \\ ( ${ }^{*}$ fendieks@gmail.com)
}

\begin{abstract}
ABSTRAK
Wanita pascamenopause rentan menderita obesitas. Susu kedelai dan bubur kacang hijau mengandung serat dan flavonoid yang bermanfaat sebagai antiobesitas. Penelitian ini bertujuan untuk menganalisis pengaruh susu kedelai dan bubur kacang hijau terhadap lingkar pinggang pada wanita pascamenopause. Penelitian ini merupakan penelitian eksperimen dengan desain pre-posttest dengan kelompok kontrol. Penelitian dilakukan selama 4 minggu dari Desember 2018 - Januari 2019 di Serengan, Surakarta. Subjek dibagi secara acak menjadi kelompok kontrol $(\mathrm{n}=10)$, susu kedelai $(\mathrm{n}=10)$ dan kombinasi susu kedelai dan bubur kacang hijau $(\mathrm{n}=10)$. Dosis susu kedelai dan bubur kacang hijau yang disediakan masing-masing adalah $240 \mathrm{ml}$ dan $180 \mathrm{ml} / \mathrm{hari} /$ orang dan diberikan selama 4 minggu penuh. Data dianalisis dengan t-test berpasangan, uji one way ANOVA dan uji post Hoc Bonferroni. Tidak ada perbedaan yang bermakna pada status gizi, pekerjaan dan tingkat pendidikan dari ketiga kelompok. Ada penurunan lingkar pinggang yang signifikan baik pada kelompok susu kedelai dan kelompok kombinasi dibandingkan dengan kelompok kontrol $(p<0,05)$. Penurunan rerata lingkar pinggang adalah $-2.40 \pm 2.23 \mathrm{~cm}$ pada kelompok susu kedelai dan $-5.30 \pm 3.20 \mathrm{~cm}$ pada kelompok kombinasi. Susu kedelai dan bubur kacang hijau bisa menjadi terapi alternatif untuk mengurangi lingkar pinggang bagi wanita pascamenopause. Kata kunci : Kedelai, kacang hijau, pascamenopause, lingkar pinggang
\end{abstract}

\section{ABSTRACT}

Postmenopausal women are prone to obesity. Soy milk and mung bean porridge contain fiber and flavonoids which are beneficial as anti-obesity. This study aimed to analyze the effect of soy milk and mung bean porridge on waist circumference among postmenopausal women. This was an experimental study using pre-posttest with the control group. The study was conducted for 4 weeks from December 2018 to January 2019 in Serengan, Surakarta. Subjects were randomly divided into control group $(n=10)$, soy milk $(n=10)$ and combination of soy milk and mung bean porridge $(n=10)$. Soy milk and mung bean porridge provided were 240 $\mathrm{ml}$ and $180 \mathrm{ml} /$ day/person and given for 4 weeks, respectively. Data were then analyzed with paired t-test, one way ANOVA and Bonferroni test. There were no significant differences in the nutritional status, occupation and education level of the three groups. There was a significant reduction in waist circumference in both the soy milk and combination group compared to the control group $(p<0.05)$. The mean decrease in waist cirumference was $-2.40 \pm 2.23 \mathrm{~cm}$ in the soy milk group and $-5.30 \pm 3.20 \mathrm{~cm}$ in the combination group. Soy milk and mung bean porridge can be alternative therapies to reduce waist circumference among postmenopausal women. Keywords : Soy, mung bean, postmenopause, waist circumference 


\section{PENDAHULUAN}

Obesitas adalah keadaan penumpukan lemak tubuh yang berlebih. Secara nasional, prevalensi obesitas sentral pada tahun 2018 semakin meningkat, yakni $31,0 \%$, lebih tinggi jika dibandingkan dengan prevalensi pada tahun 2013 yaitu sebesar $26,6 \% .^{1}$ Obesitas sentral atau dikenal juga sebagai obesitas abdominal didefinisikan sebagai peningkatan lemak perut dan merupakan salah satu tanda sindrom metabolik dan dapat diketahui melalui pemeriksaan antropometri. Salah satu pemeriksaan antropometri yang sederhana namun sangat penting adalah lingkar pinggang. Lingkar pinggang $>80 \mathrm{~cm}$ pada wanita dikategorikan sebagai berisiko tinggi terkena sindrom metabolik. ${ }^{2}$ Obesitas sentral merupakan faktor risiko penyakit kardiovaskuler dan sering terjadi pada wanita menopause. ${ }^{3,4} \mathrm{Hal}$ ini bisa dikarenakan faktor hipoestrogenemia yang cepat, gizi yang tidak sehat, aktivitas fisik yang kurang serta kadar hormon sex hormone binding globulin yang rendah. ${ }^{5}$ Selain itu, obesitas sentral seringkali berkorelasi positif dengan kadar trigliserida darah yang juga merupakan salah satu indikator sindrom metabolik. $^{6}$

Perubahan diet adalah elemen kunci dalam penanganan lini pertama pada obesitas. ${ }^{7}$ Kacang kedelai (Glycine max) dan kacang hijau (Vigna radiata) adalah jenis kacang yang memiliki banyak manfaat kesehatan, salah satunya adalah sebagai antiobesitas. Bagi wanita dengan berat badan lebih, kacang kedelai juga bisa menurunkan lingkar pinggang, terutama pada usia lebih dari 50 tahun. ${ }^{8,9}$ Hal ini bisa disebabkan karena kacang kedelai mengandung rendah kalori, $0 \%$ kolesterol, $0 \%$ asam lemak trans, tinggi protein, tinggi isoflavon, tinggi serat dan rendah lemak. ${ }^{10,11}$ Selain itu, saponin di dalam kacang kedelai memiliki efek antiobesitas dengan cara menghambat adipogenesis, lipase pankreatik, absorpsi lemak dan menghambat regulasi nafsu makan. ${ }^{12}$ Sama halnya dengan kacang kedelai, kacang hijau memiliki kalori yang rendah serta protein dan serat yang tinggi sehingga bisa meningkatkan rasa kenyang tapi tidak mudah meningkatkan lemak tubuh. Selain itu, kacang jenis ini juga mengandung resistant starch yang menghambat deposisi lemak di sel adiposit serta mengandung vitexin dan isovitexin yang bisa mencegah inflamasi di dalam tubuh. Hal ini semua bisa menurunkan risiko terjadinya obesitas. ${ }^{13,14}$

Kacang kedelai dalam bentuk susu dan kacang hijau dalam bentuk bubur adalah salah satu minuman dan makanan selingan yang paling sering dikonsumsi masyarakat Indonesia. Penelitian tentang susu kedelai dan bubur kacang hijau serta pengaruhnya secara langsung terhadap lingkar pinggang belum banyak dilakukan terutama pada wanita pascamenopause. Tujuan dari penelitian ini adalah untuk menganalisis pengaruh susu kedelai dan bubur kacang hijau terhadap lingkar pinggang wanita pascamenopause.

\section{BAHAN DAN METODE}

Penelitian ini adalah penelitian eksperimen dengan menggunakan pre-post test with control group design. Status gizi awal dari subjek dari ketiga kelompok perlakuan tidak terdapat perbedaan dari lingkar pinggang. Kriteria inklusi dalam penelitian ini adalah wanita berusia 45-75 tahun yang minimal sudah 1 tahun berhenti menstruasi (pascamenopause). Pascamenopause adalah masa kehidupan wanita setelah 12 bulan dari menstruasi terakhir. ${ }^{15}$ Sedangkan kriteria eksklusi yang diterapkan adalah menjalani diet penurunan berat badan, mengonsumsi alkohol, pernah terdiagnosis penyakit jantung koroner, gagal jantung, gagal ginjal berat, stroke dan kanker yang diketahui dari anamnesis dan rekam medis, pernah mengalami alergi terhadap kacang kedelai dan kacang hijau, imobilitas dan merokok. Imobilitas ditemukan sebagai salah satu faktor risiko obesitas. ${ }^{16}$ Penyakit berat seperti penyakit stroke, jantung koroner, gagal ginjal dan kanker juga dieksklusikan dikarenakan untuk menjaga keamanan subjek saat melakukan diet dan olahraga sesuai anjuran. Alkohol dan merokok juga diyakini sebagai penyebab dari kenaikan trigliserida darah pada orang dewasa yang mana trigliserida berkorelasi positif dengan obesitas sentral. ${ }^{17,18}$ Intervensi dilakukan di Kelurahan Joyotakan dan Kelurahan Danukusuman, Kecamatan Serengen, Surakarta. Penarikan subjek dilakukan dengan menggunakan consecutive sampling, dengan total subjek penelitian berjumlah 30 subjek yang didapatkan dari rumus Murti tentang perbandingan mean dua populasi. ${ }^{19}$ 


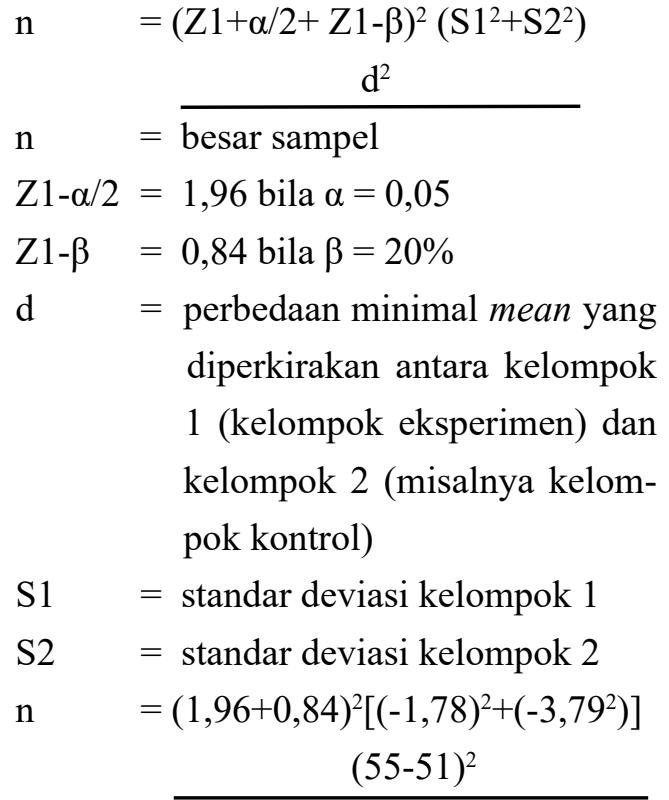

Angka 55 dan 51 didapatkan dari mean persen kelompok kontrol dan kelompok perlakuan dari penelitian Keshavarz et al. (2012). Sedangkan angka $-1,78$ dan $-3,79$ adalah standar deviasi dari kelompok kontrol dan kelompok perlakuan. Dari rumus di atas didapatkan besar sampel setiap kelompok penelitian adalah $\mathrm{n}=8,59$, sehingga besar sampel ketiga kelompok adalah 26 sampel. Untuk mengantisipasi loss to follow up $10 \%$ maka digenapkan menjadi 30 sampel yang dibagi tiga kelompok sehingga setiap kelompok terdapat 10 sampel. Penelitian crossover randomized clinical trial yang dilakukan Keshavarz et al. menemukan bahwa pemberian $240 \mathrm{ml}$ selama 4 minggu berturut-turut pada 24 orang obesitas dan kelebihan berat badan bisa menurunkan lingkar pinggang yang bermakna, namun subjek penelitian ini tidak spesifik kepada wanita pascamenopause. $^{20}$

Setelah itu, dilakukan acak sederhana untuk menentukan kelompok kontrol $(\mathrm{n}=10)$, kelompok yang mendapat susu kedelai $(\mathrm{n}=10)$ dan kelompok kombinasi susu kedelai dan bubur kacang hijau $(n=10)$. Semua subjek mendapat penyuluhan gizi secara lisan dan tulisan $1 \mathrm{kali} /$ minggu selama 4 minggu. Semua subjek dari ketiga kelompok dikumpulkan bersama-sama selama 90 menit pada hari Sabtu setiap minggu. Pada saat penyuluhan subjek diberikan brosur dan pemaparan secara lisan tentang diet rendah lemak dan rendah koles- terol sesuai pedoman Kemenkes RI. ${ }^{21}$ Penyuluhan berisi anjuran mengurangi asupan lemak, kolesterol dan karbohidrat sederhana serta meningkatkan asupan serat. Untuk menilai asupan makan subjek selama intervensi, dilakukan food recall 24 jam sebanyak 3 kali. Recall dilakukan pada hari ke-4, hari ke-15 dan hari ke-22 selama intervensi. Aktivitas fisik subjek selama intervensi berlangsung dihitung dengan global physical activity questionnaire (GPAQ) untuk menilai apakah ada pengaruh aktivitas fisik subjek terhadap penurunan lingkar pinggang. GPAQ adalah kuesioner yang dikembangkan oleh WHO untuk menilai aktivitas fisik di banyak negara yang terdiri dari 16 pertanyaan dan mencakup 3 hal yakni aktivitas saat kerja, bepergian dari suatu tempat ke tempat lain dan aktivitas saat santai. ${ }^{22}$

Dosis susu kedelai yang dipakai dalam penelitian ini adalah sebanyak $240 \mathrm{ml} /$ per subjek/per hari yang didapatkan dari studi Keshavarz et al. ${ }^{20}$ Susu kedelai dibuat sesuai pedoman dari Fitrianti $\&$ Marthandaru yang meneliti pengaruh langsung susu kedelai terhadap kolesterol total dan tidak berbeda jauh dengan cara pembuatan yang lazim di masyarakat Surakarta. ${ }^{23}$ Pembuatannya adalah sebagai berikut: kacang kedelai yang telah dibilas dan dicuci terlebih dahulu, direndam dalam air dengan perbandingan kedelai dan air 1:2 selama kurang lebih 8 jam, kemudian kulit ari kedelai dibersihkan dan dibuang. Setelah itu, kedelai direbus selama sekitar 15 menit. Kedelai yang telah direbus tadi diblender dengan perbandingan kedelai dan air $1: 3,5$. Selanjutnya diambil sarinya lalu direbus sampai mendidih sambil diaduk, setelah itu didinginkan lalu ditambahkan
Tabel 1. Kandungan Gizi Susu Kedelai dan Bubur Kacang Hijau yang dipakai dalam Penelitian ini

\begin{tabular}{lcc}
\hline \multicolumn{1}{c}{ Zat Gizi } & Susu Kedelai & $\begin{array}{c}\text { Bubur Kacang } \\
\text { Hijau }\end{array}$ \\
\hline Air (\%) & 95,34 & 89,64 \\
Abu (\%) & 0,23 & 0,47 \\
Lemak (\%) & 1,13 & 0,17 \\
Protein (\%) & 1,57 & 2,56 \\
Serat Kasar (\%) & 0,21 & 0,30 \\
Karbohidrat (\%) & 1,78 & 7,17 \\
\hline Kalori (kal/g) & $\mathbf{2 5 , 6 4}$ & $\mathbf{7 2 , 3 7}$ \\
\hline
\end{tabular}

Sumber: Data Primer, 2019 
gula rendah kalori merek tropicana slim classic sebanyak 0,5 g (1 kkal) untuk setiap $240 \mathrm{ml}$. Dosis bubur kacang hijau yang dipakai adalah $180 \mathrm{ml} /$ per subjek/hari yang didapatkan dari studi Tachibana. ${ }^{24}$ Penelitian ini menemukan bahwa dosis optimal protein kacang hijau untuk menurunkan trigliserida darah adalah $4,5 \mathrm{~g}$ protein yang setelah dikonversi menjadi $180 \mathrm{ml}$ bubur kacang hijau/orang. Bubur kacang hijau dibuat sesuai dengan cara lazim yang dipakai masyarakat sekitar. Bubur kacang hijau dibuat sesuai dengan cara lazim yang dipakai masyarakat sekitar. Pembuatannya adalah sebagai berikut: kacang hijau yang telah dicuci terlebih dahulu sebanyak 4 kali, direbus hingga mendidih, lalu direndam dalam air selama 5 jam dengan perbandingan kacang hijau dan air 1:3, lalu direbus sekitar 30 menit hingga terasa lunak. Pada setiap $180 \mathrm{ml}$ bubur kacang hijau ditambahkan gula merah 5,6 gram (22 kkal) dan garam 0,2 gram, kemudian diaduk hingga rata lalu didinginkan. Nilai gizi susu kedelai dan bubur kacang hijau yang dipakai di dalam penelitian bisa dilihat pada (Tabel 1).

Sebelum intervensi, telah dilakukan uji hedonik pada populasi serupa tentang dosis maksimal, kesukaan dan penerimaan calon subjek terhadap susu kedelai dan bubur kacang hijau. Data terdiri dari data primer lingkar pinggang pretest

Tabel 2. Karakteristik Subjek Penelitian $(n=30)$ (sebelum intervensi) dan posttest (setelah intervensi). Lingkar pinggang diukur sesuai standar WHO dengan menggunakan pita ukur lingkar pinggang yang sudah dikalibrasi dan dilakukan oleh petugas yang sudah terlatih. Data yang sudah terkumpul diolah menggunakan $t$-test berpasangan, uji one way ANOVA dan uji post hoc Bonferroni. Penelitian ini telah disetujui oleh Komisi Etik Penelitian Kesehatan (KEPK) Universitas Sebelas Maret dengan nomor sertifikat 349/UN27.6/KEPK/2018. Intervensi dilakukan selama 4 minggu penuh dari 17 Desember 2018 16 Januari 2019. Pemberian susu kedelai sebagai makanan selingan dilakukan 3 jam setelah makan siang, sedangkan pemberian bubur kacang hijau yang juga sebagai makanan selingan dilakukan 1 jam setelah pemberian susu kedelai. Pemberian dilakukan langsung setiap hari oleh staf peneliti di rumah masing-masing dan susu kedelai dan bubur kacang hijau dikonsumsi langsung oleh subjek di depan staf peneliti dan dicatat di lembar observasi.

\section{HASIL}

Subjek yang ikut dalam penelitian ini adalah 30 orang dan tidak ada yang dropout. Karakteristik subjek penelitian yang diukur terdiri dari status gizi, tingkat pendidikan, pekerjaan, rerata usia, rerata indeks massa tubuh (IMT) dan skor

\begin{tabular}{lccc}
\hline \multicolumn{1}{c}{ Karakteristik } & $\begin{array}{c}\text { Kontrol } \\
(\mathbf{n = 1 0 )} \%\end{array}$ & $\begin{array}{c}\text { Susu kedelai } \\
(\mathbf{n = 1 0 )} \%\end{array}$ & $\begin{array}{c}\text { Susu Kedelai \& Bubur } \\
\text { Kacang Hijau (n=10) \% }\end{array}$ \\
\hline Status gizi & & & \\
$\quad$ Normal & $2(20 \%)$ & $2(20 \%)$ & $2(20 \%)$ \\
$\quad$ Overweight & $2(20 \%)$ & $3(30 \%)$ & $2(20 \%)$ \\
Preobese & $3(30 \%)$ & $5(50 \%)$ & $5(50 \%)$ \\
Obesitas & $3(30 \%)$ & $0(0 \%)$ & $1(10 \%)$ \\
Tingkat Pendidikan & & & $6(60 \%)$ \\
SD & $1(10 \%)$ & $2(20 \%)$ & $2(20 \%)$ \\
SLTP & $3(30 \%)$ & $5(50 \%)$ & $2(20 \%)$ \\
SLTA & $3(30 \%)$ & $2(20 \%)$ & $0(0 \%)$ \\
Sarjana & $3(30 \%)$ & $1(10 \%)$ & $6(60 \%)$ \\
Pekerjaan & & & $4(40 \%)$ \\
IRT & $8(80 \%)$ & $7(70 \%)$ & $0(0 \%)$ \\
Wiraswasta & $1(10 \%)$ & $1(10 \%)$ & 58,4 \\
Karyawan & $1(10 \%)$ & $2(20 \%)$ & 25,7 \\
Rerata Usia (Tahun) & 56,1 & 59,5 & 536 \\
Rerata IMT & 27,5 & 25,9 & \\
Rerata Skor GPAQ & 694 & 562 & \\
\hline
\end{tabular}

GPAQ : Global Physical Activity Questionnaire

Sumber : Data Primer, 2019 
Tabel 3. Data Rerata Tiga Kali Food Recall 24 jam Selama Intervensi

\begin{tabular}{lccccc}
\hline \multicolumn{1}{c}{ Kelompok } & $\begin{array}{c}\text { Rerata Energi } \\
\text { (Kkal) }\end{array}$ & $\begin{array}{c}\text { Rerata Protein } \\
\text { (g) }\end{array}$ & $\begin{array}{c}\text { Rerata Lemak } \\
(\mathbf{g})\end{array}$ & $\begin{array}{c}\text { Rerata } \\
\text { Karbohidrat (g) }\end{array}$ & $\begin{array}{c}\text { Rerata Serat } \\
\text { (g) }\end{array}$ \\
\hline Kontrol & 1397,6 & 45,0 & 45,8 & 209,9 & 12,8 \\
Susu Kedelai & 1696,1 & 67,1 & 58,7 & 230,9 & 20,2 \\
Kombinasi & 1366,7 & 53,8 & 48,6 & 183,7 & 17,0 \\
\hline
\end{tabular}

Sumber: Data Primer, 2019

Tabel 4. Uji t Berpasangan Penurunan Rerata Lingkar Pinggang (LP) pada Ketiga Kelompok

\begin{tabular}{llcccc}
\hline \multicolumn{1}{c}{ Kelompok } & $\mathbf{n}$ & $\begin{array}{c}\text { LP }(\text { Mean } \pm \text { SD) } \\
\text { sebelum }(\mathbf{c m})\end{array}$ & $\begin{array}{c}\text { LP }(\text { Mean } \pm \text { SD) } \\
\text { sesudah }(\mathbf{c m})\end{array}$ & $\begin{array}{c}\Delta \text { Mean } \\
(\mathbf{c m})\end{array}$ & Nilai p \\
\hline Kontrol & 10 & $95,35 \pm 7,59$ & $95.60 \pm 7,48$ & $-0,25 \pm 0,58$ & 0,213 \\
Susu Kedelai & 10 & $94,65 \pm 8,16$ & $92.25 \pm 6,99$ & $-2,40 \pm 2,23$ & 0,008 \\
Kombinasi & 10 & $93,00 \pm 7,79$ & $87.70 \pm 5,31$ & $-5,30 \pm 3,20$ & 0,001 \\
\hline
\end{tabular}

Sumber: Data Primer, 2019

Tabel 5. Uji Post Hoc Bonferroni Perbedaan Penurunan Lingkar Pinggang pada Ketiga Kelompok

\begin{tabular}{ccc}
\hline Kelompok 1 & Kelompok 2 & Nilai p \\
\hline Kontrol & Susu Kedelai & 0,045 \\
Kontrol & Kombinasi & $<0,001$ \\
Susu Kedelai & Kombinasi & 0,025 \\
\hline
\end{tabular}

Sumber: Data Primer, 2019

Global Physical Activity Questionnaire (GPAQ). Rerata usia tertinggi terdapat pada kelompok susu kedelai dan rerata IMT tertinggi terdapat pada kelompok kontrol. IMT dari ketiga kelompok tidak terdapat perbedaan bermakna. Subjek yang praobesitas serta tingkat pendidikan SD terbanyak ada pada kelompok kombinasi susu kedelai dan bubur kacang hijau. Aktivitas fisik subjek yang dihitung dengan GPAQ menunjukkan skor aktivitas fisik terendah terjadi pada kelompok kombinasi susu kedelai dan bubur kacang hijau dan diikuti oleh kelompok susu kedelai (Tabel 2). Rerata asupan energi, lemak, protein, serat dan karbohidrat tertinggi ada pada kelompok susu kedelai (Tabel 3).

Penurunan lingkar pinggang yang signifikan hanya terjadi pada kelompok susu kedelai $(-2.40 \pm 2.23 \mathrm{~cm})$ dan kelompok kombinasi susu kedelai dan bubur kacang hijau $(-5.30 \pm 3.20 \mathrm{~cm})$ (Tabel 4). Perbandingan penurunan lingkar pinggang yang bermakna pada uji post hoc Bonferroni terjadi pada semua kelompok $(\mathrm{p}<0,05)$ (Tabel 5).

\section{PEMBAHASAN}

Penurunan lingkar pinggang pada kelompok susu kedelai bisa disebabkan oleh pengaruh diet rendah lemak dan rendah kolesterol yang dijalankan subjek penelitian sesuai anjuran penyuluhan gizi serta efek positif dari susu kedelai sebagai minuman kaya serat, asam lemak omega-3, rendah karbohidrat, tinggi protein dan fitokimia lainnya. Hal ini bisa terlihat dari skor GPAQ yang rendah dan asupan energi, lemak dan karbohidrat yang lebih tinggi pada kelompok susu kedelai bila dibandingkan dengan kelompok kontrol, akan tetapi hasil penelitian pada kelompok susu kedelai justru menurunkan lingkar pinggang. Lingkar pinggang pada kelompok kombinasi juga terlihat menurun lebih besar dibandingkan kelompok lainnya. Hal ini bisa disebabkan oleh efek sinergi dari susu kedelai dan bubur kacang hijau. Resistant starch yang terkandung di dalam kacang hijau bisa membantu meningkatkan oksidasi lemak dan menurunkan simpanan lemak di dalam adiposit, sehingga bermanfaat sebagai antiobesitas. ${ }^{13}$

Banyak faktor yang bisa meningkatkan risiko terjadinya obesitas seperti kurang aktivitas fisik, gangguan tidur, faktor psikologis, faktor ekonomis, makanan tinggi kalori dan makanan manis. ${ }^{25}$ Faktor usia dan jenis kelamin juga bisa menjadi penyebab terjadinya obesitas terutama pada anggota keluarga miskin. Usia di atas 25 tahun dan faktor jenis kelamin perempuan di- 
temukan berhubungan dengan kejadian obesitas. ${ }^{26}$ Konsumsi glukosa, sukrosa dan laktosa bisa meningkatkan pengeluaran insulin sehingga menjadi cepat lapar dan asupan energi meningkat. Fruktosa atau gula buah sebaliknya bisa diproses tanpa insulin tapi bisa meningkatkan lipogenesis de novo sehingga triasilgliserol atau trigliserida naik dan pada akhirnya terjadi gangguan metabolik. ${ }^{27}$

Kalori dari bubur kacang hijau yang dipakai pada penelitian ini masih lebih tinggi daripada kalori susu kedelai. Hal tersebut bisa terjadi karena pemakaian gula merah di dalam bubur kacang hijau. Gula merah diketahui mengandung kalori yang cukup tinggi sehingga bisa meningkatkan risiko obesitas. Untuk menurunkan kalori dari bubur kacang hijau, gula merah sebaiknya bisa digantikan dengan gula rendah kalori dengan tetap memperhatikan rasa dan penerimaan subjek. Pemakaian pemanis rendah kalori disarankan karena bisa mengurangi sedikit berat badan, indeks massa tubuh, massa lemak dan lingkar pinggang. ${ }^{28}$ Gula merah atau gula jawa memiliki indeks glikemik sekitar 42 dan setiap 100 g gula merah mengandung $386 \mathrm{kkal}^{29,30}$ Uji hedonik yang dilakukan pada populasi serupa memang menunjukkan bahwa pemakaian gula merah pada bubur kacang hijau lebih bisa diterima dibandingkan jenis gula lainnya. Lain halnya dengan bubur kacang hijau, pemakaian gula rendah kalori pada susu kedelai masih bisa diterima.

Akhlaghi et al. menyatakan bahwa kacang kedelai bisa bermanfaat untuk menurunkan lingkar pinggang terutama bagi wanita yang berusia tua. ${ }^{9}$ Selain itu, Keshavarz et al. juga menyatakan bahwa, pemberian susu kedelai $240 \mathrm{ml}$ selama 4 minggu kepada subjek yang obesitas dan kelebihan berat badan yang nonmenopause bisa menurunkan lingkar pinggang yang signifikan secara statistik. Penurunan lingkar pinggang berhubungan dengan kandungan fitoestrogen dan protein susu kedelai seperti beta conglycinin yang memainkan peran penting untuk mengurangi akumulasi lemak. Namun, pemberian susu kedelai yang singkat tidak berpengaruh pada berat badan, kontrol indeks glikemik, enzim hati, fibrinogen dan tekanan darah. ${ }^{20}$ Isoflavon kedelai tidak mempengaruhi tekanan darah pada subjek yang normotensif dan nonmenopause. ${ }^{31}$
Penelitian $\mathrm{Hu}$ et al. menunjukkan serat yang terkandung di dalam kedelai bisa membantu menurunkan berat badan, IMT dan Low-Density Lipoprotein (LDL) puasa terutama pada orang dewasa yang kelebihan berat badan dan obesitas. ${ }^{16}$ Peradangan kronis tingkat rendah dalam jaringan adiposa telah diakui sebagai langkah kunci dalam pengembangan komplikasi terkait obesitas. Asam lemak omega-3 bermanfaat memperbaiki status peradangan di jaringan adiposa dan mengurangi disfungsi metabolik akibat dari obesitas. ${ }^{32}$

Asupan makan pada kelompok susu kedelai termasuk tinggi kalori dan tinggi lemak bila dibandingkan dengan kelompok lainnya. Aktivitas fisik kelompok susu kedelai juga termasuk rendah yang bisa dilihat dari skor GPAQ 562 yang masih termasuk kategori aktivitas fisik tingkat rendah. Namun, kedua hal ini bisa menyingkirkan kemungkinan penurunan lingkar pinggang akibat dari peningkatan aktivitas fisik dan penurunan asupan makan. Hal ini sesuai dengan penelitian dari Choi et al. tentang peningkatan aktivitas fisik bisa menurunkan lingkar pinggang pada wanita menopause. ${ }^{33}$

Asupan lemak pada kelompok kombinasi yang didapat dari food recall 24 jam termasuk lebih tinggi daripada kelompok kontrol. Begitu juga aktivitas fisiknya yang lebih rendah dari kelompok kontrol. Sebagian besar subjek dari kelompok susu kedelai dan kelompok kombinasi berpendidikan di bawah SLTA. Hal ini bisa menjadi faktor penghambat bagi kepatuhan dan penerimaan terhadap apa yang dianjurkan pada penyuluhan gizi. Penyuluhan yang diberikan mencakupi anjuran diet rendah lemak, rendah karbohidrat terutama karbohidrat sederhana serta tinggi serat, akan tetapi data dari food recall justru menunjukkan hasil yang sebaliknya yakni asupan serat yang kurang, serta asupan lemak dan karbohidrat yang masih tinggi walaupun angka tersebut masih di bawah AKG. Penelitian ini tentu saja masih memiliki beberapa keterbatasan yakni sampel yang kecil dan cakupan penelitian yang tidak begitu luas.

\section{KESIMPULAN DAN SARAN}

Pemberian susu kedelai pada wanita pascamenopause sebanyak $240 \mathrm{ml}$ selama 4 minggu berturut-turut bisa menurunkan lingkar pinggang 
sebesar 2,40 $\pm 2,23 \mathrm{~cm}$ dan kelompok kombinasi susu kedelai dan bubur kacang hijau sebesar 5,30 $\pm 3,20 \mathrm{~cm}$ yang bermakna secara statistik dan pemberian kombinasi susu kedelai $240 \mathrm{ml}$ dan bubur kacang hijau $180 \mathrm{ml}$ selama 4 minggu juga bisa menurunkan lingkar pinggang lebih besar daripada pemberian susu kedelai saja. Hal ini bisa dijadikan terapi alternatif bagi wanita pascamenopause untuk menurunkan lingkar pinggang sehingga diharapkan bisa mengurangi risiko penyakit kardiovaskuler di kemudian hari.

Berdasarkan hasil penelitian ini, dapat disarankan: susu kedelai dan bubur kacang hijau dapat dijadikan makanan selingan sehari-hari yang menyehatkan terutama bagi wanita pascamenopause, diperlukan kehati-hatian dalam menambahkan gula pada susu kedelai dan bubur kacang hijau sehingga tidak meningkatkan kalori, untuk menurunkan kalori dari bubur kacang hijau, gula merah sebaiknya bisa digantikan dengan gula rendah kalori dengan tetap memperhatikan rasa dan penerimaan subjek, serta aktivitas fisik dan olahraga yang rutin tentunya juga diperlukan untuk membantu menurunkan lingkar pinggang.

\section{DAFTAR PUSTAKA}

1. Kemenkes RI. Riset Kesehatan Dasar (RISKESDAS). Jakarta: Balitbang Kemenkes RI; 2018.

2. WHO. Waist Circumference and Waist-Hip Ratio: Report of a WHO Expert Consultation Geneva; 2008.

3. Huxley R, Mendis S, Zheleznyakov E, et al. Body Mass Index, Waist Circumference and Waist: Hip Ratio as Predictors of Cardiovascular Risk - A Review of the Literature. European Journal of Clinical Nutrition. 2010;64(1):16-22.

4. Gravena A, Brischiliari S, Lopes T, Agnolo C, Carvalho M \& Pelloso S. Excess Weight and Abdominal Obesity in Postmenopausal Brazilian Women: A Populationbased Study. BMC Women's Health. 2013;13(1): 46.

5. Kozakowski J, Gietka-Czernel, Leszczynska D \& Majos A. Obesity in Menopause - Our Negligence or an Unfortunate Inevitability? Menopause Review. 2017;16 (2):61-65.

6. Zhang A, Yao Y, Xue Z, Guo X, Dou J, Lu Y, et al. A Study on the Factors Infuencing Tri- glyceride Levels among Adults in Northeast China. Scientific Reports. 2018;8(1): 6388.

7. Simpson SA, Shaw $C \&$ McNamara R. What is the Most Effective Way to Maintain Weight Loss in Adults? British Medical Journal. 2011;343. Available at: https://www.bmj. com/content/343/bmj.d8042

8. Ganesan K, Xu B. A Critical Review on Phytochemical Profile and Health Promoting Effects of Mung Bean (Vigna radiata). Food Science and Human Wellness.2018;7(1);11-33.

9. Akhlaghi M, Zare M \& Nouripour F. Effect of Soy and Soy Isoflavones on Obesity-Related Anthropometric Measures: A Systematic Review and Meta-analysis of Randomized Controlled Clinical Trials. Advance in Nutrition. 2017;8(5):705-717.

10. Yanai H, Katsuyama H, Hamasaki H, Abeb S, Tadab N \& Sako A. Effects of Soy Protein and Isoflavones Intake on HDL Metabolism in Asian Populations. Journal of Endocrinology and Metabolism. 2014;4(3):51-55.

11. USDA (United States Department of Agriculture).USDA Food Composition Databases 2018. [Diakses pada 12 Juli 2018]. Available at: https://ndb.nal.usda.gov/ndb/search/list.

12. Marelli M, Conforti F, Araniti F \& Statti GA. Effects of Saponins on Lipid Metabolism: A Review of Potential Health Benefits in the Treatment of Obesity. Molecules. 2016;21(1404):1-20.

13. Higgins J. Resistant Starch and Energy Balance: Impact on Weight Loss and Maintenance. Critical Reviews in Food Science and Nutrition. 2014;54(9):1158-1166.

14. Li H, Cao D, Yi J, Cao J \& Jiang W. Identification of the Flavonoids in Mungbean (Phaseolus radiatus L) Soup and Their Antioxidant Activities. Food Chemistry. 2012;135(4):2942-2946.

15. Ward K \& Deneris A. An Update on Menopause Management. Journal of Midwifery and Women's Health. 2018;63(2):167-177.

16. Hu X, Gao J, Zhang Q, Fu Y, Li K, Zhu S, et $a l$. Soy Fiber Improves Weight Loss and Lipid Profile in Overweight and Obese Adults: A Randomized Controlled Trial. Molecular Nutrition and Food Research. 2013;57(12): 2147-2154. 
17. Berglund L, Brunzell JD, Goldberg AC, Goldberg IJ, Sack F, Murad MH, et al. Evaluation and Treatment of Hypertriglyceridemia: An Endocrine Society Clinical Practice Guideline. The Journal of Clinical Endocrinology and Metabolism.2012;97(9);2969-2989.

18. Johnson RK, Appel LJ, Brands M, Howard $\mathrm{BV}$, Lefevre M, Lustig RH, et al. On Behalf of the American Heart Association Nutrition Committee of the Council on Nutrition, Physical Activity, and Metabolism and the Council on Epidemiology and Prevention. Dietary Sugars Intake and Cardiovascular Health: a Scientific Statement from the American Heart Association. Circulation.2009;120(11): 1011-1020.

19. Murti B. Prinsip dan Metode Riset Epidemiologi. Edisi Keempat. Program Studi Ilmu Kesehatan Masyarakat. Surakarta: Pascasarjana Universitas Sebelas Maret; 2016.

20. Keshavarz SA, Nourieh Z, Attar MJH \& Azadbaht L. Effect of Soy Milk Consumption on Waist Circumference and Cardiovascular Risks among Overweight and Obese Female Adults. International Journal of Preventive Medicine. 2012;3(11):798-805.

21. Kemenkes RI. Diet Rendah Lemak dan Kolesterol. Jakarta: Direktorat Bina Gizi Subdit Gizi Klinik; 2011.

22. WHO. Global Physical Activity Questionnaire (GPAQ) Analysis Guide. [Diakses pada 10 Agustus 2018]. Available at: www.who. int.

23. Fitrianti DY \& Marthandaru D. Pengaruh Susu Kedelai dan Jahe terhadap Kadar Kolesterol Total pada Wanita Hiperkolesterolemia. Jurnal Gizi Indonesia. 2016;4(2):89-95.

24. Tachibana N, Wanezaki S, Nagata M, Motoyama T, Kohno M \& Kitagawa S. Intake of Mung Bean Protein Isolate Reduces Plasma Triglyceride Levelin Rats. Functional Foods in Health and Disease. 2013;3(9):365-376.

25. Hruby A \& Hu FB. The Epidemiology of Obesity: A Big Picture. Pharmacoeconomics, 2015;33(7):673-689.

26. Nadimin, Ayumar \& Fajarwati. Obesitas pada Orang Dewasa Anggota Keluarga Miskin di Kecamatan Lembang Kabupaten Pinrang. Media Kesehatan Masyarakat Indonesia. 2015;11(3):9-15.

27. Aller EEJG, Abete I, Astrup A, Martinez JA \& Van Baak MA. Starches, Sugars and Obesity. Nutrients. 2011;3(3): 341-369.

28. Miller P \& Perez V. Low-calorie Sweeteners and Body Weight and Composition: A Meta-analysis of Randomized Controlled Trials and Prospective Cohort Studies. American Journal of Clinical Nutrition. 2014;100(3): 765-777.

29. Trinidad TP, Mallillin AC, Sagum RS \& Encabo RR. Glycemic Index of Commonly Consumed Carbohydrate Foods in the Philippines. Journal of Functional Foods. 2010;2: 271-274.

30. Kemenkes RI. Data Komposisi Pangan Indonesia 2017. [Diakses pada 4 Juni 2018]. Available at: www.panganku.org.

31. Liu XX, Li SH, Chen JZ, Sun K, Wang XJ, Wang XG, et al. Effect of Soy Isoflavones on Blood Pressure: A Meta-Analysis of Randomized Controlled Trials. Nutrition, Metabolism and Cardiovascular Diseases. 2011;22:463470.

32. Titos E \& Claria J. Omega-3-derived Mediators Counteract Obesity-induced Adipose Tissue Inflammation. Prostaglandins and Other Lipid Mediators. 2013;107(1):77-84.

33. Choi JW, Guiterres Y, Gilliss C, Lee KA. Physical Activity, Weight and Waist Circumference in Midlife Women. Health Care Women International. 2012;33(12):1086-1095. 